\title{
SENSITIVITY OF WINTER WHEAT CULTIVARS TO SELECTED HERBICIDES
}

\author{
Renata Kieloch*, Henryka Rola \\ Institute of Soil Science and Plant Cultivation, Research State Institute, Orzechowa 61, 50-540 Wrocław, Poland
}

Received: March 20, 2009

Accepted: October 27, 2009

\begin{abstract}
The experiments on tolerance of winter wheat cultivars to herbicides were performed under field conditions during 2003-2005 in the region of Wrocław (South-West of Poland). Five cultivars were examined (Zyta, Tonacja, Sukces, Clever, Kobra). Two herbicide mixtures: isoproturon + pendimethalin and diflufenican + flurtamon were applied in the autumn, in stage of 3-4 leaves. In the spring, when wheat reached stage of full tillering, the following herbicides were used: florasulam + 2.4-D and fluroxypyr + 2.4-D. Phytotoxicity of herbicides was determined on the base of plants vigour assessment, plants counting, yield and some yield components. During the experimental period, impact of the mixture pendimethalin + isoproturon on grain yield of Clever cultivar was observed only in the season with hard winter conditions (2002/2003). The remaining varieties: Zyta, Tonacja, Sukces and Kobra were completely tolerant to this herbicide mixture. Mild winter seasons did not show a negative influence of herbicides on grain yield of tested varieties. All cultivars showed a complete tolerance to diflufenican + flurfamon and florasulam + 2.4-D. The mixture fluroxypyr + 2.4-D caused ear deformation of all tested wheat cultivars, but did not affect negatively grain yield.
\end{abstract}

Key words: winter wheat, cultivar, tolerance, herbicides, yield, plant density, weather conditions

\section{INTRODUCTION}

The chemical weed control, apart from undeniable profits, brings about a negative effect as well. Both agricultural practice and previous studies proved that in some cases herbicides are not completely selective to a particular crop. Their application can result in visible crop injuries i.e. leaf chlorosis, necrosis, plant deformations, decolorization, leaves withering, growth retardation (Gabińska and Rola 1985; Petróczi et al. 2002). Generally, these symptoms are temporary and do not influence grain yield, however in certain cases, yield reduction was reported. Wheat tolerance to herbicides is primarily determined by genetic properties of a cultivar, but it can be strongly modified by cultivation regime and weather conditions. The main reason for winter wheat cultivars different tolerance to herbicide are diverse viability to plant metabolic and morphologic properties that govern herbicide uptake and translocation (Cabanne et al. 1985; Dagstheib and Field 1990).

Significant percentage of wheat in crop rotation leads to increased weed infestation. Chemical weed control makes it possible to maintain the field weed-free and, consequently, it affects grain yield. The Polish market of fers on abundant range of herbicides for weed control in winter wheat. New winter wheat cultivars are registered in Poland each year and this fact makes the researchers continue the investigation on tolerance of winter wheat varieties to herbicides.

*Corresponding address:

r.kieloch@iung.wroclaw.pl
The aim of this investigation was to determine the reaction of five winter wheat cultivars to selected herbicides.

\section{MATERIALS AND METHODS}

The field investigations on winter wheat cultivars tolerance to herbicides were carried out in the years 2003-2005 in the region of Wrocław. There were examined five currently registered in Poland cultivars (Zyta, Sukces, Tonacja, Clever, Kobra). Experiments were set up on black soil. Individual plot size was $2 \times 8 \mathrm{~m}$. The experiment followed a split-plot pattern with four replications. In each experimental period winter wheat was sowed in the middle of October. A sowing rate of each wheat cultivars amounted to 450 plants per $\mathrm{m}^{2}$. All agricultural treatments, including cultivation, fertilization and plant protection, were performed according to general recommendations for this crop.

The herbicides were applied using a plot sprayer "Gloria" equipped with four TeeJet 11003 VS flat fan nozzles. The sprayer was operated at the speed of $3.6 \mathrm{~km} / \mathrm{h}$ and pressure $0,25 \mathrm{MPa}$, a spray volume amounted to $250 \mathrm{l} / \mathrm{ha}$. Table 1 shows the data for four tested herbicides, their doses and the time of treatments.

Herbicide phytotoxicity was assessed by visual method at the following dates: a. for autumn application -2-3 weeks after treatment, just after beginning of plant growing period, in the spring and during wheat heading, b. for spring treatment - 2-3 weeks after spraying and during plants heading. A 1-9 scale was used: 1 - no crop 
Table 1. Characteristics of tested herbicides

\begin{tabular}{|c|c|c|c|}
\hline Herbicide & Trade name & Dose $[\mathrm{g} / \mathrm{ha}]$ & Date of application \\
\hline Pendimethalin + isoproturon & Maraton 375 SC & $1000+500$ & \multirow{2}{*}{$\begin{array}{c}\text { autumn, stage of } 2-4 \text { leaves of } \\
\text { wheat }\end{array}$} \\
\hline Diflufenican + flurtamon & Carat 350 SC & $75+187.5$ & \\
\hline Florasulam + 2.4-D & Mustang $306 \mathrm{SE}$ & $3.75+180$ & \multirow{2}{*}{$\begin{array}{l}\text { spring, stage of full tillering } \\
\text { of wheat }\end{array}$} \\
\hline Fluroxypyr + 2.4-D & Gold 450 EC & $112.5+450$ & \\
\hline
\end{tabular}

injury, 9 - total crop damage. The influence of herbicide on overwintering of winter wheat was also based on visual assessment and by counting plants on $1 \mathrm{~m}^{2}$ at the early spring. Wheat was harvested at complete maturity stage using a harvester Nurserymaster Elite Z 035. Grain yield was estimated on each plot. Weight of 1000 grains was determined according to national standard PN-68/R-74017.

The data obtained were analysed using analysis of variance to evaluate the significance of differences.

\section{RESULTS}

\section{The weather conditions}

In 2002/2003 season, in the autumn wheat growth was interrupted when plants reached stage of 2 leaves. This season was characterized by hard winter - long period with the temperature below $0^{\circ} \mathrm{C}$ and the lack of snow cover. Such conditions did not favoured winter survival of the examined plant species. In the spring plant growing period began at the end of March, but low temperature during the first decade of April temporarily slowed down plants growth. On average, all spring-summer period was warm and characterized by low rainfall. The weather conditions in 2003/2004 could be described as mild winter, which was favourable for wheat over wintering. In the spring plant growth started in the last decade of March. Spring and summer season were mildly warm and rather dry. In the next growing season (2004/2005), September and the first decade of October were warm, with sufficient rainfall. In the autumn plant growing period was over rather early - half of November. When the winter dormancy began, plants reached 2 leaves phase and had poorly developed root system. Weather conditions in the winter (average temperature above $0^{\circ} \mathrm{C}$, and snowfall) favoured plant overwintering. The beginning of March was cold, with the temperature slightly below $0^{\circ} \mathrm{C}$. The temperature increased in the first decade of April and spring growing period started. Spring and summer period were comparatively cold and wet, with total rainfall of $210 \mathrm{~mm}$ (April-June). These conditions did not favour wheat development and seed setting. Heavy rainfall in the July resulted in delayed harvesting of winter wheat.

\section{The influence of herbicides on crop status, plant den- sity and yield}

The autumn evaluation of phytotoxic effect of mixtures combining isoproturon + pendimethalin and diflufenican + flurtamon did not show crop damage of tested cultivars in each experimental period. Visible injuries occurred on plants of Clever cultivar just after the beginning of plant growing period in the spring and resulted from hard win- ter conditions (2002/2003). The plots treated with the mixture pendimethalin + isoproturon were thinned markedly and leaf withering was observed. Remaining varieties did not respond to tested herbicides. During the following plant growing seasons detrimental effects of this mixture did not occur. Among herbicides applied in the spring, florasulam + 2.4-D did not negatively affect plant vigour. After the mixture fluroxypyr + 2.4-D application, visual injuries were not observed during the first assessment, but during plant heading were recorded ear deformation of each tested varieties (Table 2).

Wheat plant density significantly differed within the whole experimental period at cultivar level. The most pronounced differences between varieties were observed in 2002/2003, when Tonacja cultivar showed the highest plant density (more than 600 plants per square meter), while Clever cultivar belonged to the least dense (average 184 plants per square meter). Both herbicides and cultivars considerably affected plant number in that season. Cultivar Clever proved to negatively react to the mixture pendimethalin + isoproturon, which led to significant wheat thinning as compared to the untreated plots. The remaining varieties did not show reduction of plant number, irrespective of herbicides used. In the subsequent seasons (2003/2004, 2004/2005), there were not observed any essential differences regarding both herbicides and a cultivars (Table 3 ).

The yield of tested winter wheat cultivars showed a considerable diversity in different growing seasons. During 2004/2005 grain yield of wheat reached a significantly higher level in comparison to the others seasons, whereas in 2002/2003 and 2003/2004 wheat yielding was similar. In $2002 / 2003$, the yield of Clever cultivar was markedly lower than that of other wheat varieties, regardless of herbicide applied. The cultivar mentioned above also showed on essential yield reduction after application the mixture pendimethalin + isoproturon. During the subsequent plant growing seasons, diversity involved only wheat cultivars, but not herbicides. There were not recorded any interactions between cultivars and herbicides (Table 4).

Weight of 1000 grains did not vary within experimental period as far as herbicides were taken into account, but it was different for the examined cultivars. Only weight of 1000 grain of cultivar Sukces was similar for each plant growing season, while the remaining ones showed different values regarding the years. Significantly low value of this parameter was obtained for Clever cultivar in 2002/2003. The latter one produced considerable smaller grains in comparison with other cultivars. None of the herbicides affected weight of 1000 grains of wheat, but differences regarding cultivars were recorded in each season (Table 5). 
Table 2. The influence of herbicides on plant vigour of winter wheat cultivar (scale 1-9)

\begin{tabular}{|c|c|c|c|c|c|c|c|c|c|c|c|c|c|c|c|c|}
\hline \multirow{3}{*}{ Season } & \multirow{3}{*}{ Herbicides } & \multicolumn{15}{|c|}{ Cultivars } \\
\hline & & \multicolumn{3}{|c|}{ ZYTA } & \multicolumn{3}{|c|}{ SUKCES } & \multicolumn{3}{|c|}{ TONACJA } & \multicolumn{3}{|c|}{ CLEVER } & \multicolumn{3}{|c|}{ KOBRA } \\
\hline & & I & II & III & I & II & III & I & II & III & I & II & III & I & II & III \\
\hline \multirow{5}{*}{$\begin{array}{l}2002 / \\
2003\end{array}$} & untreated & 1 & 1 & 1 & 1 & 1 & 1 & 1 & 1 & 1 & 1 & 1 & 1 & 1 & 1 & 1 \\
\hline & $\begin{array}{l}\text { pendimethalin } \\
\text { + isoproturon }\end{array}$ & 1 & 1 & 1 & 1 & 1 & 1 & 1 & 1 & 1 & 1 & 5 & 5 & 1 & 1 & 1 \\
\hline & $\begin{array}{l}\text { diflufenican } \\
+ \text { flurtamon }\end{array}$ & 1 & 1 & 1 & 1 & 1 & 1 & 1 & 1 & 1 & 1 & 1 & 1 & 1 & 1 & 1 \\
\hline & florasulam + 2.4-D & - & 1 & 1 & - & 1 & 1 & - & 1 & 1 & - & 1 & 1 & - & 1 & 1 \\
\hline & fluroxypyr + 2.4-D & - & 1 & 2 & - & 1 & 2 & - & 1 & 2 & 1 & 1 & 2 & - & 1 & 2 \\
\hline \multirow{5}{*}{$\begin{array}{l}2003 / \\
2004\end{array}$} & untreated & 1 & 1 & 1 & 1 & 1 & 1 & 1 & 1 & 1 & 1 & 1 & 1 & 1 & 1 & 1 \\
\hline & $\begin{array}{l}\text { pendimethalin } \\
+ \text { isoproturon }\end{array}$ & 1 & 1 & 1 & 1 & 1 & 1 & 1 & 1 & 1 & 1 & 1 & 1 & 1 & 1 & 1 \\
\hline & $\begin{array}{l}\text { diflufenican } \\
+ \text { flurtamon }\end{array}$ & 1 & 1 & 1 & 1 & 1 & 1 & 1 & 1 & 1 & 1 & 1 & 1 & 1 & 1 & 1 \\
\hline & florasulam + 2.4-D & - & 1 & 1 & - & 1 & 1 & - & 1 & 1 & - & 1 & 1 & - & 1 & 1 \\
\hline & fluroxypyr + 2.4-D & - & 1 & 1 & - & 1 & 1 & - & 1 & 1 & 1 & 1 & 1 & - & 1 & 1 \\
\hline \multirow{5}{*}{$\begin{array}{l}2004 / \\
2005\end{array}$} & untreated & 1 & 1 & 1 & 1 & 1 & 1 & 1 & 1 & 1 & 1 & 1 & 1 & 1 & 1 & 1 \\
\hline & $\begin{array}{l}\text { pendimethalin } \\
+ \text { isoproturon }\end{array}$ & 1 & 1 & 1 & 1 & 1 & 1 & 1 & 1 & 1 & 1 & 1 & 1 & 1 & 1 & 1 \\
\hline & $\begin{array}{l}\text { diflufenican } \\
+ \text { flurtamon }\end{array}$ & 1 & 1 & 1 & 1 & 1 & 1 & 1 & 1 & 1 & 1 & 1 & 1 & 1 & 1 & 1 \\
\hline & florasulam + 2.4-D & - & 1 & 1 & - & 1 & 1 & - & 1 & 1 & - & 1 & 1 & - & 1 & 1 \\
\hline & fluroxypyr + 2.4-D & - & 1 & 1 & - & 1 & 1 & - & 1 & 1 & 1 & 1 & 1 & - & 1 & 1 \\
\hline
\end{tabular}

I - autumn assessment, II - spring assessment, III - pre-harvest assessment

Table 3. The influence of herbicides on plant density [plants $/ \mathrm{m}^{2}$ ] of winter wheat cultivars

\begin{tabular}{|c|c|c|c|c|c|c|c|}
\hline \multirow{2}{*}{ Season } & \multirow{2}{*}{ Herbicides } & \multicolumn{5}{|c|}{ Cultivars } & \multirow{2}{*}{$\begin{array}{l}\text { Average for } \\
\text { herbicides }\end{array}$} \\
\hline & & ZYTA & SUKCES & TONACJA & CLEVER & KOBRA & \\
\hline \multirow{5}{*}{$2002 / 2003$} & untreated & 360 & 430 & 613 & 203 & 515 & 432 \\
\hline & pendimethalin + isoproturon & 363 & 445 & 613 & $130^{*}$ & 498 & 410 \\
\hline & diflufenican + flurtamon & 350 & 430 & 608 & 218 & 555 & 432 \\
\hline & average for cultivars & 358 & 435 & 611 & 184 & 523 & - \\
\hline & \multicolumn{7}{|c|}{ LSD (0.05) for: cultivars 52.747 herbicides n.s. herbicides x cultivars 68.050} \\
\hline \multirow{5}{*}{$2003 / 2004$} & untreated & 450 & 400 & 487 & 323 & 473 & 427 \\
\hline & pendimethalin + isoproturon & 457 & 383 & 470 & 302 & 453 & 413 \\
\hline & diflufenican + flurtamon & 437 & 413 & 460 & 310 & 423 & 417 \\
\hline & average for cultivars & 448 & 404 & 472 & 312 & 450 & - \\
\hline & \multicolumn{7}{|c|}{ LSD (0.05) for: cultivars 31.978 herbicides n.s. herbicides $x$ cultivars n.s. } \\
\hline \multirow{5}{*}{$2004 / 2005$} & untreated & 355 & 403 & 360 & 385 & 378 & 376 \\
\hline & pendimethalin +isoproturon & 360 & 400 & 383 & 395 & 392 & 389 \\
\hline & diflufenican + flurtamon & 368 & 393 & 368 & 400 & 390 & 384 \\
\hline & average for cultivars & 361 & 399 & 370 & 393 & 387 & - \\
\hline & \multicolumn{7}{|c|}{ LSD (0.05) for: cultivars 33.881 herbicides n.s. herbicides $x$ cultivars n.s. } \\
\hline \multirow{5}{*}{$\begin{array}{c}2003- \\
2005\end{array}$} & untreated & 388 & 411 & 487 & 304 & 455 & 409 \\
\hline & pendimethalin + isoproturon & 393 & 409 & 489 & $277^{*}$ & 447 & 403 \\
\hline & diflufenican + flurtamon & 385 & 412 & 479 & 309 & 456 & 408 \\
\hline & average for cultivars & 389 & 411 & 485 & 297 & 453 & - \\
\hline & LSD (0.05) for: & $\mathrm{kye}-2 y$ & $.51 \mathrm{~h}$ & vears $n$ & bicide & ars 21 & \\
\hline
\end{tabular}

*significant reduction as compared to untreated 
Table 4. The influence of herbicides on grain yield [t/ha] of winter wheat cultivars

\begin{tabular}{|c|c|c|c|c|c|c|c|}
\hline \multirow{2}{*}{ Season } & \multirow{2}{*}{ Herbicides } & \multicolumn{5}{|c|}{ Cultivars } & \multirow{2}{*}{$\begin{array}{c}\text { Average for } \\
\text { herbicides }\end{array}$} \\
\hline & & ZYTA & SUKCES & TONACJA & CLEVER & KOBRA & \\
\hline \multirow{7}{*}{$\begin{array}{l}2002 / \\
2003\end{array}$} & untreated & 6.39 & 6.73 & 6.43 & 6.10 & 6.41 & 6.41 \\
\hline & pendimethalin + isoproturon & 6.63 & 6.42 & 6.41 & $5.44^{*}$ & 6.40 & 6.26 \\
\hline & diflufenican + flurtamon & 6.56 & 6.65 & 6.83 & 6.21 & 6.88 & 6.63 \\
\hline & florasulam + 2.4-D & 6.96 & 6.61 & 6.61 & 6.37 & 6.27 & 6.56 \\
\hline & fluroxypyr + 2.4-D & 6.36 & 6.73 & 6.76 & 5.91 & 6.53 & 6.46 \\
\hline & average for cultivars & 6.58 & 6.63 & 6.61 & 6.00 & 6.50 & - \\
\hline & \multicolumn{7}{|c|}{ LSD (0.05) for: cultivars 0.249 herbicides n.s. herbicides $\mathrm{x}$ cultivars 0.460} \\
\hline \multirow{7}{*}{$\begin{array}{l}2003 / \\
2004\end{array}$} & untreated & 7.22 & 6.51 & 6.43 & 6.82 & 5.81 & 6.56 \\
\hline & pendimethalin + isoproturon & 7.21 & 6.34 & 6.48 & 6.80 & 5.56 & 6.48 \\
\hline & diflufenican + flurtamon & 7.60 & 6.77 & 6.65 & 7.17 & 5.90 & 6.82 \\
\hline & florasulam + 2.4-D & 7.67 & 6.69 & 6.63 & 7.37 & 5.93 & 6.86 \\
\hline & fluroxypyr + 2.4-D & 7.35 & 6.62 & 6.49 & 7.35 & 6.23 & 6.81 \\
\hline & average for cultivars & 7.41 & 6.59 & 6.54 & 7.10 & 5.89 & - \\
\hline & \multicolumn{7}{|c|}{ LSD $(0.05)$ for: cultivars 0.354 herbicides n.s. herbicides $x$ cultivars n.s. } \\
\hline \multirow{7}{*}{$\begin{array}{l}2004 / \\
2005\end{array}$} & untreated & 6.54 & 6.74 & 6.62 & 8.22 & 6.37 & 6.90 \\
\hline & pendimethalin + isoproturon & 6.59 & 6.91 & 6.88 & 8.29 & 6.67 & 7.07 \\
\hline & diflufenican + flurtamon & 6.58 & 7.20 & 6.99 & 8.74 & 6.94 & 7.29 \\
\hline & florasulam + 2.4-D & 6.74 & 6.79 & 6.73 & 8.37 & 6.84 & 7.09 \\
\hline & fluroxypyr + 2.4-D & 6.64 & 7.09 & 7.09 & 8.72 & 6.74 & 7.26 \\
\hline & average for cultivars & 6.62 & 6.95 & 6.86 & 8.47 & 6.71 & - \\
\hline & \multicolumn{7}{|c|}{ LSD $(0.05)$ for: cultivars 0.267 herbicides n.s. herbicides $x$ cultivars n.s. } \\
\hline \multirow{6}{*}{$\begin{array}{c}2003- \\
2005\end{array}$} & untreated & 6.72 & 6.66 & 6.49 & 7.05 & 6.20 & 6.62 \\
\hline & pendimethalin + isoproturon & 6.81 & 6.55 & 6.59 & $6.84^{*}$ & 6.21 & 6.60 \\
\hline & diflufenican + flurtamon & 6.91 & 6.87 & 6.82 & 7.37 & 6.57 & 6.91 \\
\hline & florasulam + 2.4-D & 7.12 & 6.90 & 6.66 & 7.37 & 6.35 & 6.88 \\
\hline & fluroxypyr + 2.4-D & 6.78 & 6.81 & 6.78 & 7.33 & 6.50 & 6.84 \\
\hline & average for cultivars & 6.87 & 6.76 & 6.67 & 7.19 & 6.37 & - \\
\hline
\end{tabular}

*significant reduction as compared to untreated; n.s. - not significant differences

Table 5. The influence of herbicides on weight of 1000 grains [g] of winter wheat cultivars

\begin{tabular}{|c|c|c|c|c|c|c|c|}
\hline \multirow{2}{*}{ Season } & \multirow{2}{*}{ Herbicides } & \multicolumn{5}{|c|}{ Cultivars } & \multirow{2}{*}{$\begin{array}{c}\text { Average for } \\
\text { herbicides }\end{array}$} \\
\hline & & ZYTA & SUKCES & TONACJA & CLEVER & KOBRA & \\
\hline \multirow{7}{*}{$\begin{array}{l}2002 / \\
2003\end{array}$} & untreated & 45.8 & 45.6 & 47.0 & 42.9 & 44.7 & 45.2 \\
\hline & pendimethalin + isoproturon & 43.9 & 48.0 & 47.6 & 40.9 & 46.1 & 45.3 \\
\hline & diflufenican + flurtamon & 46.5 & 47.1 & 47.7 & 41.7 & 46.3 & 45.9 \\
\hline & florasulam + 2.4-D & 46.2 & 46.4 & 48.5 & 42.7 & 45.3 & 45.8 \\
\hline & fluroxypyr $+2.4-\mathrm{D}$ & 46.1 & 47.7 & 47.4 & 44.0 & 45.9 & 46.2 \\
\hline & average for cultivars & 45.7 & 46.9 & 47.4 & 42.4 & 45.7 & - \\
\hline & \multicolumn{7}{|c|}{ LSD (0.05) for: cultivars 1.618 herbicides n.s. herbicides $x$ cultivars n.s. } \\
\hline \multirow{7}{*}{$\begin{array}{l}2003 / \\
2004\end{array}$} & untreated & 45.0 & 45.5 & 47.5 & 41.7 & 49.7 & 45.9 \\
\hline & pendimethalin + isoproturon & 46.8 & 45.1 & 47.1 & 41.6 & 49.6 & 46.0 \\
\hline & diflufenican + flurtamon & 45.2 & 43.9 & 48.4 & 43.9 & 48.8 & 46.0 \\
\hline & florasulam + 2.4-D & 46.0 & 47.4 & 45.9 & 44.1 & 48.2 & 46.3 \\
\hline & fluroxypyr + 2.4-D & 44.3 & 46.4 & 45.3 & 42.9 & 49.9 & 45.8 \\
\hline & average for cultivars & 45.5 & 45.7 & 46.8 & 43.0 & 49.2 & - \\
\hline & \multicolumn{7}{|c|}{ LSD $(0.05)$ for: cultivars 2.441 herbicides n.s. $\quad$ herbicides $x$ cultivars n.s } \\
\hline \multirow{7}{*}{$\begin{array}{l}2004 / \\
2005\end{array}$} & untreated & 48.4 & 48.1 & 48.6 & 40.0 & 42.4 & 45.5 \\
\hline & pendimethalin + isoproturon & 48.4 & 49.7 & 48.7 & 38.9 & 46.5 & 46.4 \\
\hline & diflufenican + flurtamon & 47.9 & 49.1 & 48.2 & 38.9 & 44.1 & 45.6 \\
\hline & florasulam + 2.4-D & 48.8 & 48.7 & 46.6 & 39.1 & 42.7 & 45.0 \\
\hline & fluroxypyr + 2.4-D & 48.9 & 50.8 & 51.4 & 39.3 & 45.0 & 47.1 \\
\hline & average for cultivars & 48.5 & 49.3 & 48.5 & 39.2 & 44.1 & - \\
\hline & \multicolumn{7}{|c|}{ LSD (0.05) for: cultivars 1.903 herbicides n.s. herbicides $x$ cultivars n.s. } \\
\hline \multirow{7}{*}{$\begin{array}{c}2003- \\
2005\end{array}$} & untreated & 46.4 & 46.4 & 47.7 & 41.5 & 45.6 & 45.5 \\
\hline & pendimethalin + isoproturon & 46.4 & 47.6 & 47.8 & 40.5 & 47.4 & 45.9 \\
\hline & diflufenican + flurtamon & 46.5 & 46.7 & 48.1 & 41.5 & 46.4 & 45.8 \\
\hline & florasulam + 2.4-D & 47.0 & 47.5 & 46.7 & 42.0 & 45.4 & 45.7 \\
\hline & fluroxypyr + 2.4-D & 46.5 & 48.3 & 48.0 & 42.1 & 46.9 & 46.4 \\
\hline & average for cultivars & 46.6 & 47.3 & 47.7 & 41.5 & 46.3 & - \\
\hline & 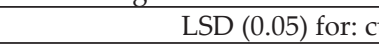 & & & & & & \\
\hline
\end{tabular}




\section{DISCUSSION}

The influence of tested herbicides on winter wheat varied between experimental seasons. The weather conditions profoundly affected winter wheat cultivars' tolerance to herbicides. Significant yield reduction resulting from herbicide application occurred during 2002/2003, when winter conditions were hard for wheat overwintering - long period with temperature below $0^{\circ} \mathrm{C}$ and the lack of snow cover. It is well known fact that weather conditions affect herbicides' activity, both their efficacy and phytotoxicity. Low temperature retards herbicide metabolism in plants, which finds its reflection in longer persistence of plant injuries (Gauvrit and Gaillardon 1991; Cashimore et al. 1995). In this experiment visible plant injuries were not observed in the autumn, but the first injuries appeared in the early spring on plots treated with the mixture pendimethalin + isoproturon. It seems likely that weather conditions negatively affected plant vigour, because during hard winter they contributed to plant weakness and, consequently, higher sensitivity to a herbicide. The results obtained in this investigation evidently show that yield reduction of Clever cultivar was caused by plant thinning, which resulted poor overwintering during unfavourable weather conditions. This cultivar is susceptible to damage due to winter hardiness and this property in combination with herbicidal stress probably decreased the ability of winter survival. The adverse effect of hard winter conditions on wheat tolerance to herbicides and different cultivars reaction to herbicides was observed in previous studies (Rola et al. 1999; Adamczewski and Urban 2000). The remaining cultivars did not reveal any negative reaction to pendimethalin + isoproturon mixture. This fact shows for evident differences in winter wheat cultivars tolerance to herbicides and it confirms the results obtained in the previous studies (Sikkema et al. 2007; Kong et al. 2009).

A negative reaction of winter wheat to growth regulator herbicides, which contain for example 2.4-D and MCPA, was reported previously (Nowicka 1993; Orr et al. 1996). These herbicides caused leaf rolling, ear deformation and, in some cases, yield loss. Presented study showed only ear deformation as a result of the mixture fluroxypyr + 2.4-D application, but plant damage was temporary and did not affect grain yield.

\section{CONCLUSIONS}

Considering introduction of new winter wheat cultivars to agricultural practice, the studies on wheat tolerance should be continued to obtain detailed, useful for farmers information. The research aims at answering the question if particular herbicide can be applied in specific cultivar without risk of yield loss. On the basis of results of our investigation, the application of the mixture pendimethalin + isoproturon should be avoided in cultivar Clever.

\section{REFERENCES}

Adamczewski K., Urban M. 2000. Reakcja 7 odmian pszenicy ozimej na dwie formy użytkowe chlorotoluronu. Prog. Plant Protection/Post. Ochr. Roślin 40 (1): 374-379.

Cabanne F., Gaillardon P., Scalla R. 1985. Phytotoxicity and metabolism of chlortoluron in two wheat cultivars. Pestic. Biochem. Physiol. 23: 212-220.

Cashimore W.J., Caseley J.C. 1995. Effect of low doses of herbicides, temperature and simulated harrowing on the survival of three weed species. Proc. Brighton Crop Protection Conference - Weeds, 20-23 November 1995, Brighton, United Kingdom, 6 C-16: 719-725.

Dastgheib F., Field R.J. 1990. Differential response of wheat to chlorsulfuron. Proc. of the 43th New Zealand Weed and Pest Control Conference, 14-16 August 1990, Dunedin, New Zealand 43: 150-153.

Gabińska K., Rola J. 1985. Reakcja odmian pszenicy ozimej na herbicydy. Pam. Puł. 84: 103-120.

Gauvrit C., Gaillardon P. 1991. Effect of low temperatures on 2,4$\mathrm{D}$ behaviour in maize plants. Weed Res. 31: 135-142.

Kong L., Si J., Feng B., Li S., Wang F., Sayre K. 2009. Differential responses of two types of winter wheat (Triticum aestivum L.) to autumn- and spring-applied mesosulfuron-methyl. Crop Protect. XXX: 1-6.

Nowicka B. 1993. Wpływ herbicydów na wysokość i jakość plonu odmian pszenicy ozimej. Praca doktorska, Wyd. IUNG Puławy, R (302), 47 pp.

Petróczi I.M., Matuz J., Kótai C. 2002. Study of pesticide sideeffects in winter wheat trials. Proc. of the 7th Hungarian Congress on Plant Physiology, 24-27 June 2002, Szeged, Hungary 46 (3-4): 207-208.

Orr J.P., Canevari M., Jackson L., Wennimg R., Carner R., Nishimoto G. 1996. Postemergence herbicides and application time affect wheat yields. Calif. Agric. 50 (4): 32-36.

Rola H., Domaradzki K., Kieloch R. 1999. Tolerancja wybranych odmian pszenicy ozimej na herbicydy. Pam. Puł. 114: 305311.

Sikkema P.H., Brown L., Shropshire Ch., Soltani N. 2007. Responses of three types of winter wheat (Triticum aestivum L.) to spring-applied post-emergence herbicides. Crop Protect. 26: 715-720.

\section{POLISH SUMMARY}

WRAŻLIWOŚĆ ODMIAN PSZENICY OZIMEJ NA WYBRANE HERBICYDY

W latach 2003-2005 w okolicach Wrocławia przeprowadzono doświadczenia polowe nad reakcją odmian pszenicy ozimej na niektóre herbicydy. W badaniach wykorzystano 5 odmian pszenicy: Zyta, Tonacja, Sukces, Clever i Kobra. Herbicydy: izoproturon + pendimetalina i diflufenikan + flurtamon zastosowano jesienia, w fazie 3-4 liści pszenicy. Środki: florasulam + 2,4-D oraz fluroxypyr + 2,4-D aplikowano wiosną $\mathrm{w}$ fazie pełni krzewienia. Fitotoksyczność herbicydów określono na podstawie wizualnej oceny kondycji roślin, obsady roślin oraz wysokości plonu i niektórych elementów jego struktury. Ujemny wpływ mieszaniny pendimetaliny z izoproturonem na plonowanie pszenicy ozimej odmiany Clever był 
obserwowany tylko w sezonie o ostrym przebiegu zimy (2002/2003). Odmiany: Zyta, Tonacja i Sukces wykazały całkowitą tolerancję. W sezonach o łagodnym przebiegu zimy nie stwierdzono negatywnego wpływu powyższego herbicydu na badane odmiany. Środki: diflufenican
+ flurtamon oraz florasulam + 2,4-D były całkowicie selektywne dla badanych odmian pszenicy. Mieszanina fluroksypyr + 2,4-D spowodowała deformację kłosów u wszystkich badanych odmian pszenicy, co jednak nie wpłynęło ujemnie na wielkość plonowania. 